\title{
Role of sclerostin in the pathogenesis of chronic kidney disease-mineral bone disorder
}

\author{
Yukari Asamiya, Ken Tsuchiya and Kosaku Nitta*
}

\begin{abstract}
Sclerostin is a 190-amino-acid glycoprotein that is mainly secreted by osteocytes, and it decreases bone formation by inhibiting the terminal differentiation of osteoblasts and promoting their apoptosis. Sclerostin blocks the Wnt signaling pathway in osteoblasts by binding to low-density lipoprotein receptor-related protein 5/6 (LRP-5/6) receptors. We reviewed the literature detailing the role of sclerostin in the pathogenesis of chronic kidney disease-bone mineral disorder (CKD-MBD). Increased serum sclerostin levels may be correlated with increased serum levels of phosphate and fibroblast growth factor 23 (FGF23) in hemodialysis patients with relatively low parathyroid hormone levels. Decreased Wnt/ $\beta$-catenin signaling occurs regardless of the overall changes in bone formation rates, suggesting that a reduction in the anabolic response may be a common feature of renal bone disorders; however, additional mechanisms may contribute to the diversity of osteodystrophy phenotypes. Recent clinical studies demonstrated that treatment with anti-sclerostin antibodies improved bone quality in the context of low but not high turnover renal osteodystrophy. Sclerostin also appears in the circulation, suggesting that it plays additional roles outside the skeleton under normal conditions and in disease states. The serum sclerostin levels in CKD patients are several times higher than in healthy subjects. Recent data suggest that the higher serum sclerostin levels are associated with increased fracture rates, but the relationship between sclerostin and cardiovascular disease is unclear. CKD stage-specific epidemiologic studies are needed to assess whether sclerostin elevations affect comorbidities associated with CKD-MBD.
\end{abstract}

Keywords: CKD-MBD, Sclerostin, Osteocyte, Renal osteodystrophy, Wnt signaling

\section{Background}

Sclerostin is a 190-residue secreted glycoprotein that is predicted to contain a cysteine-knot motif and is a member of the DAN/Cerberus protein family [1] (Fig. 1). In patients with the rare inherited bone disorder, sclerosteosis, which is characterized by exceptionally high bone density [2], have recently been found to be homozygous for a defective sclerostin gene (SOST) $[3,4]$, and a similar high bone mass phenotype has been reported in sclerostin knock-out mice [5]. Sclerostin null mice have very high bone mass, and conversely, severe osteopenia occurs in transgenic mice overexpressing sclerostin in osteocytes [6]. Sclerostin is secreted by osteocytes and has been shown to down-regulate the synthesis of several bone formation markers by osteogenic cells [7-9],

\footnotetext{
* Correspondence: knitta@kc.twmu.ac.jp

Department of Medicine, Kidney Center, Tokyo Women's Medical University, 8-1 Kawada-cho, Shinjuku-ku, Tokyo 162-8666, Japan
}

thereby indicating the importance of sclerostin in the regulation of bone formation.

Chronic kidney disease-mineral bone disorder (CKDMBD) is defined by abnormalities in mineral and hormone metabolism that lead to declining bone health and soft tissue calcification [10, 11]. Previous studies have shown that these changes are associated with increased fracture rates coupled with pathologic changes in the cardiovascular system, including reduced vascular wall elasticity, vascular calcification, and left ventricular hypertrophy $[12,13]$.

The specialized morphology of osteocytes allows them to function effectively the balance between osteoblast and osteoclast activity and regulate systemic mineral metabolism. Osteocytes are the primary sites of production of several factors important to bone and mineral metabolism, including fibroblast growth factor 23 (FGF23) and sclerostin, which are considered the key 


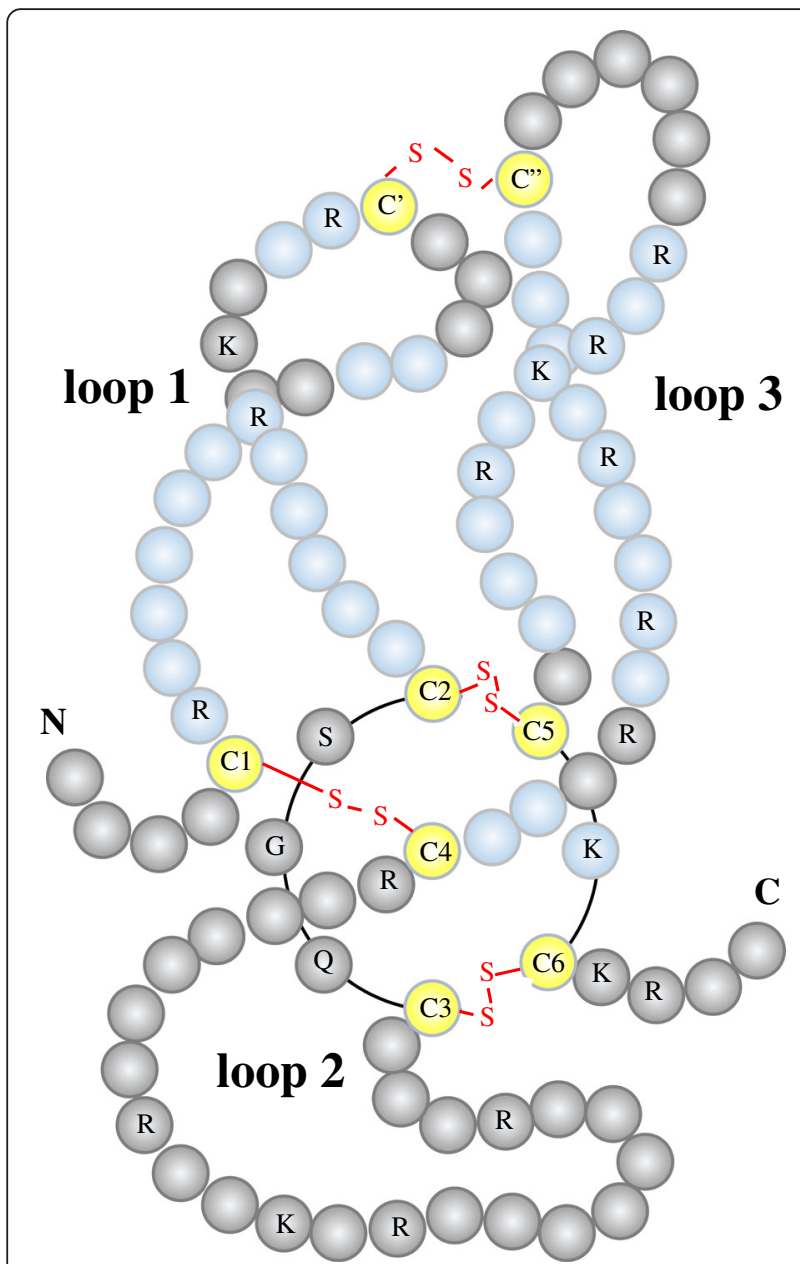

Fig. 1 Chemical structure of sclerostin. A schematic representation of the chemical structure of sclerostin, highlighting the position of the disulfide bonds, the resulting three-loop structure, and residues involved in a regular $\beta$-sheet [1]

signal transduction molecules that function as negative regulators of the Wnt/ $\beta$-catenin pathway in bone. This review describes the potential role of sclerostin in the pathogenesis of CKD-MBD.

\section{Wnt/B-catenin signaling and sclerostin}

Wnt/ $\beta$-catenin signaling plays a key role in various biological processes, including cell proliferation, cell migration, and differentiation [14]. The canonical Wnt pathway involves interactions between several Wnt ligands and their cognate receptors and co-receptors. Wnt proteins are a family of highly conserved secreted signaling molecules that regulate cell-to-cell interactions during embryogenesis. As shown in Fig. 2, Wnt ligands bind to cell surface receptor complexes that are comprised of Frizzled and low-density lipoprotein receptor-related protein (LRP) family members [14, 15]. Only unphosphorylated $\beta$-catenin can translocate into the nucleus and modulate target gene transcription (Fig. 2a). In the presence of the soluble Wnt inhibitor sclerostin, Wnt ligands are blocked from binding the LRP-5/6-Frizzled receptor complex (Fig. 2b). Since Wnt signaling encompasses vascular development and endothelial cell specification as well as regulation of bone modeling and remodeling, it appears prototypic for the crosstalk within the bone-vascular axis [16-18]. In addition to being dependent on the local expression of specialized Wnt ligands, regulation of the canonical Wnt pathway is dependent on the relative expression of inhibitors that bind to either Wnts themselves (Frizzled-related proteins, FRPs) or to one of the LRP co-receptors, such as sclerostin or Dickkopf-related protein 1 (Dkk1).

\section{Role of sclerostin in bone metabolism}

Sclerostin is mainly secreted by osteocytes, and it decreases bone formation by inhibiting the terminal differentiation of osteoblasts and promoting their apoptosis. Sclerostin blocks Wnt signaling pathway in osteoblasts by binding to LRP-5/6 receptors [19]. Osteocytes act as mechanosensors, and they initiate and regulate osteoclastogenesis by producing receptor activator of nuclear factor- $\mathrm{KB}$ ligand (RANKL) and its decoy receptor osteoprotegerin (OPG) (Fig. 3) [15, 20]. Osteocytes also regulate bone formation via the Wnt signaling pathway by secreting sclerostin and Dkk1 [21]. Sclerostin and Dkk1 bind to LRP-5/6 as Wnt co-receptors and they prevent Wnt protein binding to secreted FRPs and its coreceptors, an essential step for Wnt signaling [21]. Downstream actions of Wnt signaling result in intracellular production of $\beta$-catenin, which regulates transcription. Wnt signaling and bone morphogenetic protein are involved in osteoblastogenesis and bone formation [22]. Sclerostin is also expressed in several non-skeletal tissues, especially in the vasculature, but whether this is a cause or a consequence of vascular calcification is yet to be determined [23].

\section{Renal osteodystrophy and Wnt signaling}

Renal osteodystrophy is a syndrome of bone disorders showing from low to high bone turnover and is associated with disturbances in calcium and phosphorus homeostasis in association with hyperparathyroidism [24]. Parathyroid hormone (PTH) is known to bind directly to cells of the osteoblast/osteocyte lineage and promote increased RANKL expression, which leads to osteoclast activation. The mechanism of the predominant catabolic activity of sustained increased PTH levels is consistent with the results of studies of the effect of PTH therapy. The effect of intermittent PTH administration is transient, because RANKL actions are balanced by the subsequent rising levels of its 

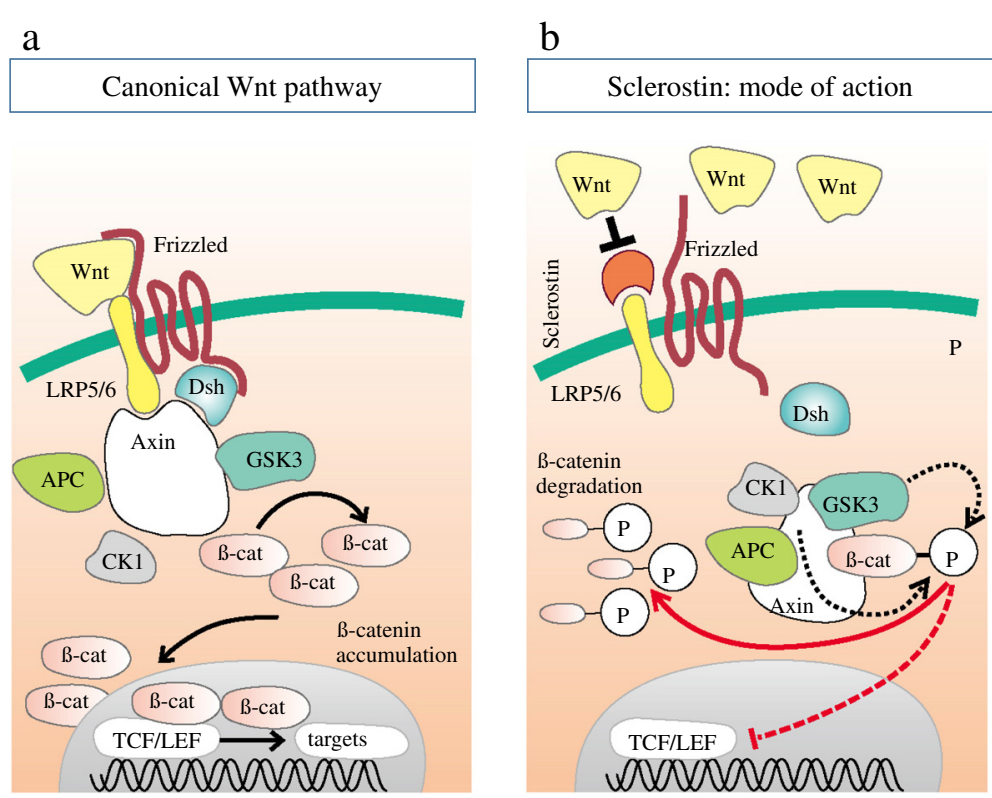

Fig. 2 Interaction between sclerostin and Wnt signaling. a Soluble Wnt ligands bind to a receptor complex consisting of Frizzled and LDL-receptorrelated protein 5/6 (LRP-5/6), and the receptor complex interacts with the phosphoprotein Dishevelled (Dsh). Wnt ligand binding and activation of Dsh result in the relocation of Axin followed by disassembly of the $\beta$-catenin degradation complex. Then, unphosphorylated $\beta$-catenin accumulates, translocates into the nucleus, and modifies gene transcription. $\mathbf{b}$ In the presence of sclerostin, a soluble Wnt inhibitor, Wnt ligands are blocked from binding the LRP-5/6-Frizzled receptor complex which in turn allows activation of the $\beta$-catenin degradation complex (CK-APCGSK3-Axin complex). Phosphorylation of $\beta$-catenin by GSK3 and CK1 blocks the translocation of $\beta$-catenin into the nucleus and increases $\beta$-catenin degradation via proteolysis [15]

antagonist, OPG, thus accounting for the short burst of osteoclast activity.

The transient activation of osteoclast activity leads to increased osteoblast activity which triggers the classic bone anabolic PTH response [25]. In contrast, catabolic activity is observed when high PTH concentrations are sustained, such as during continuous PTH therapy and in pathologic hyperparathyroidism, because RANKL expression remains high. The differential regulation of the RANKL/OPG ratio by PTH appears to occur via crosstalk with the Wnt/ $\beta$-catenin pathway [26]. The PTH/ PTH1R receptor complex has been shown to directly bind and phosphorylate the Wnt co-receptor LRP-6 in a cAMP-dependent manner, thereby promoting $\beta$-catenin stabilization in the absence of Wnt binding [27]. PTH's effect on $\beta$-catenin explains its effect on sclerostin, because sclerostin down-regulation is a classic target of $\beta$-catenin-controlled transcription. Taken together, the mechanism of high bone turnover via a PTH-dependent effect on the $\beta$-catenin pathway has been clearly demonstrated.

A recent study by Moe et al. assessed the effects of anti-sclerostin in normal animals relative to a slow progressing model of CKD-MBD with imposed low or high PTH levels [28]. Antibody treatment had no influence on bone health in CKD animals with high $\mathrm{PTH}$ and elevated bone turnover and cortical porosity.
However, the antibody improved trabecular bone volume and mineralization in CKD animals with low PTH values that had bone defects associated with low bone formation. These results correlated with a reduction in bone expression of inactive phosphorylated $\beta$ catenin, confirming its ability to restore Wnt/ $\beta$-catenin signaling. Bone strength was unchanged in CKD animals with low PTH. In normal animals, the antibody treatment improved bone volume, cortical geometry, and biomechanical properties. The failure of the antibody to improve bone strength in the context of CKD suggests that while $\beta$-catenin contributes to bone disease, restoration of Wnt binding to the receptor may not be sufficient to overcome all bone changes associated with low bone turnover osteodystrophy and that additional mechanisms may contribute to the underlying defects in CKD.

A cross-sectional study of 60 dialysis patients showed that their serum sclerostin levels were inversely correlated with the patients' bone formation rates [29]. A subsequent prospective study of 81 dialysis patients found that higher sclerostin serum concentrations predicted greater loss of bone mass over a 1-year period [30]. These findings are consistent with the hypothesis that, as would be expected of a negative regulator of bone formation, higher serum sclerostin levels promote low bone turnover, which leads to loss of bone mass over time. Additional studies are needed to determine 


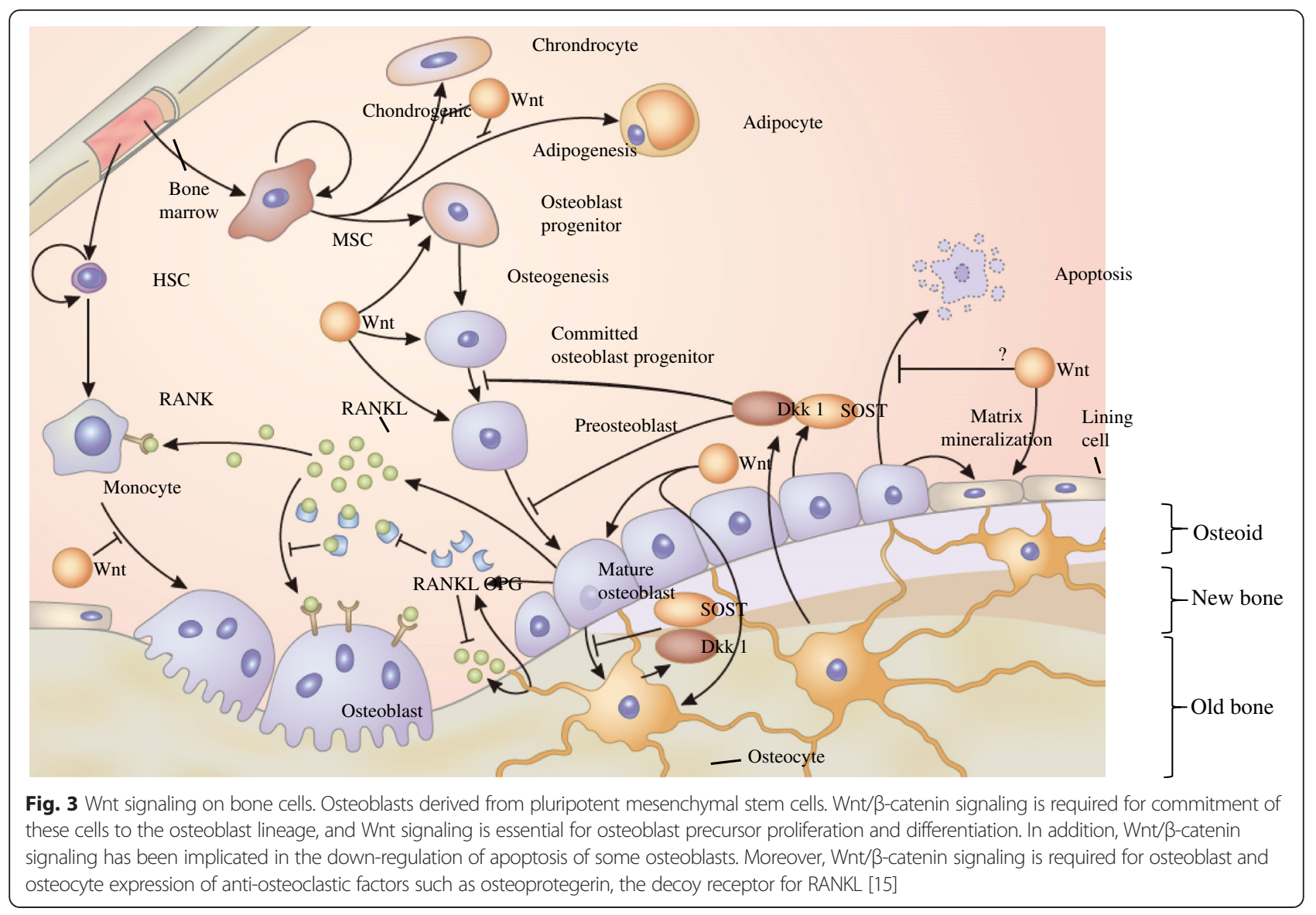

whether differential serum sclerostin levels are associated with bone disease associated with high versus low bone formation.

\section{Serum sclerostin levels in CKD}

The molecular size of sclerostin is approximately $22.5 \mathrm{kDa}$, and the majority of sclerostin is likely to be filtered through glomeruli and reabsorbed by renal tubular cells in a normal kidney. McNulty et al. reported firstly two enzyme-linked immunoassays, one for measuring serum sclerostin levels and the other for measuring plasma sclerostin levels [31], and the concentrations of sclerostin in serum and in plasma were different when determined by the two assays. A comparative study of the two assays showed that the plasma sclerostin levels were $30 \%$ higher than the serum sclerostin levels and that the intra-assay and inter-assay coefficients of variance were less than $10 \%$ and less than $20 \%$, respectively [32]. As shown in Table 1, serum sclerostin levels under various physiological and pathological conditions have been listed in a review article [33].

Serum sclerostin levels were significantly correlated with age and were higher in male than female patients with stage 3b and 4 CKD [34]. The high serum sclerostin levels of CKD patients are likely to be dependent on accumulation of sclerostin in the serum due to a decline in glomerular filtration rate (GFR) and/or increased sclerostin production by osteocytes. There is a controversy for the mechanism involved in increased serum sclerostin levels in CKD patients. For example, Cejka et al. reported that renal elimination of sclerostin increased regardless of decline in renal function and urinary sclerostin excretion increased with declining GFR [35]. Furthermore, increased extraskeletal production of sclerostin may be one of the causes of its high serum levels. For example, Roforth et al. reported that bone mRNA levels did not increase in older people regardless of their high serum sclerostin levels [36]. Circulating sclerostin levels have been found to be increased in several cohorts of CKD patients. Cejka et al. were the first to report finding increased serum sclerostin levels in a cross-sectional study of dialysis patients [37], and their finding has been validated by other studies in ESRD patients $[23,29,30,38-40]$. Pelletier et al. reported that higher serum sclerostin levels were starting at CKD stage 3 [38]. However, the degree to which serum sclerostin levels reflect changes in expression versus accumulation in individuals with impaired renal function is not fully understood. A previous study examining the local expression of sclerostin across stages of CKD revealed that 
Table 1 Changes in serum sclerostin levels in various physiologic and pathological conditions

\begin{tabular}{|c|c|c|}
\hline Condition & Directional change & Comments \\
\hline \multicolumn{3}{|l|}{ Physiologic states } \\
\hline Age: adults and elderly & Increase with age & $\begin{array}{l}\text { Serum sclerostin levels increase with age, but bone marrow sclerostin mRNA is not increased in } \\
\text { older patients. }\end{array}$ \\
\hline Gender & Higher in men & $\begin{array}{l}\text { Likely due to higher bone mass (osteocyte number); lower in premenopausal women because } \\
\text { of estrogen effect. }\end{array}$ \\
\hline Menopause & $\begin{array}{l}\text { Higher after } \\
\text { menopause }\end{array}$ & Lack of inhibitory effect of estrogen or decreased bone formation leading to low osteocyte number. \\
\hline Malnutrition & $\begin{array}{l}\text { Blunts sclerostin } \\
\text { changes }\end{array}$ & In patients with anorexia nervosa, sclerostin does not decrease with estrogen therapy. \\
\hline \multicolumn{3}{|l|}{ Hormones } \\
\hline Parathyroid hormone & Decrease & Direct effect on osteoblast, osteocyte number, and on Wnt signaling. \\
\hline Vitamin D & Increase & Limited data; one study each in normal and dialysis patients; confounding by PTH is likely. \\
\hline Estrogen & Decrease & Direct effect of estrogen and possibly SERMs on osteoblast/osteocyte number and function. \\
\hline Androgen & Data unclear & Increased in prostate cancer patients and during androgen deprivation therapy. \\
\hline Leptin & Increased & Sclerostin levels were higher in obese patient and correlated with leptin and PTH levels. \\
\hline Growth hormone/IGF & Data unclear & IGF is obligatory to the anabolic action of PTH; may be for osteocyte function and sclerostin as well. \\
\hline \multicolumn{3}{|l|}{ Pathologic conditions } \\
\hline \multicolumn{3}{|l|}{ Bone and mineral disorders } \\
\hline $\begin{array}{l}\text { Hyperparathyroidism } \\
\text { (Primary) }\end{array}$ & Decrease & $\begin{array}{l}\text { Lower levels compared with controls in untreated patients and normalize after } \\
\text { parathyroidectomy. }\end{array}$ \\
\hline Paget's disease of bone & Increased & Sclerostin did not correlate with P1NP or CTX. \\
\hline $\begin{array}{l}\text { Glucocorticoid-induced } \\
\text { osteoporosis }\end{array}$ & $\begin{array}{l}\text { Early increase/later } \\
\text { decline }\end{array}$ & Varies with timing of the study with reference to steroid use. \\
\hline Cushing's disease & Decreased & Increased after treatment, suggesting suppressive effects on osteocyte and osteoblast function. \\
\hline \multicolumn{3}{|l|}{$\begin{array}{l}\text { Osteoporosis treatment } \\
\text { effects }\end{array}$} \\
\hline $\begin{array}{l}\text { Bisphosphonates and } \\
\text { denosumab }\end{array}$ & Increase & $\begin{array}{l}\text { Results may vary due to timing of data collection after denosumab or zolendronic acid } \\
\text { administration. }\end{array}$ \\
\hline $\begin{array}{l}\text { Teriparatide and } \\
\text { strontium ranelate }\end{array}$ & Decreased & Compensatory increase in Dkk1 levels may limit continued anabolic action. \\
\hline Estrogen and raloxifene & Decreased & $\begin{array}{l}\text { Suggesting estrogen and estrogen effect of raloxifene may modulate osteocyte and osteoblast } \\
\text { function. }\end{array}$ \\
\hline \multicolumn{3}{|l|}{ Systemic disorders } \\
\hline Diabetes mellitus type 1 & Slight increase & Age-related increase maintained, but sclerostin response to PTH is blunted. \\
\hline Diabetes mellitus type 2 & Increased & $\begin{array}{l}\text { Age-related increase is absent, sclerostin response to PTH is impaired, and pioglitazone therapy } \\
\text { increases sclerostin levels by } 11 \% \text {. }\end{array}$ \\
\hline Chronic kidney disease & Increased & Sclerostin excretion increases with declining renal function with negative correlation with GFR. \\
\hline Kidney disease & Increased & Sclerostin levels increase despite increased PTH and increased excretion of sclerostin in renal failure. \\
\hline
\end{tabular}

highest osteocyte expression occurred at initial stages of the disease [41]. Although this study examined the number of sclerostin-positive osteocytes rather than absolute protein levels, the resulting data suggest that sclerostin accumulation in the serum is at least partially due to increased osteocyte production. Moreover, the rapid restoration of serum sclerostin to the normal range posttransplant suggests that decreased renal clearance may also be responsible for accumulation at least in late stages [42].
Delanaye et al. reported finding that plasma sclerostin levels in hemodialysis patients were positively associated with their phosphate levels and negatively associated with their PTH levels [43]. We have recently reported an increased serum sclerostin levels (Fig. 4) and that serum sclerostin were closely associated with serum phosphate and FGF23 levels and treatment with vitamin D in hemodialysis patients with low serum PTH levels [44]. Further study will be necessary to determine whether these relationships between serum sclerostin levels and 

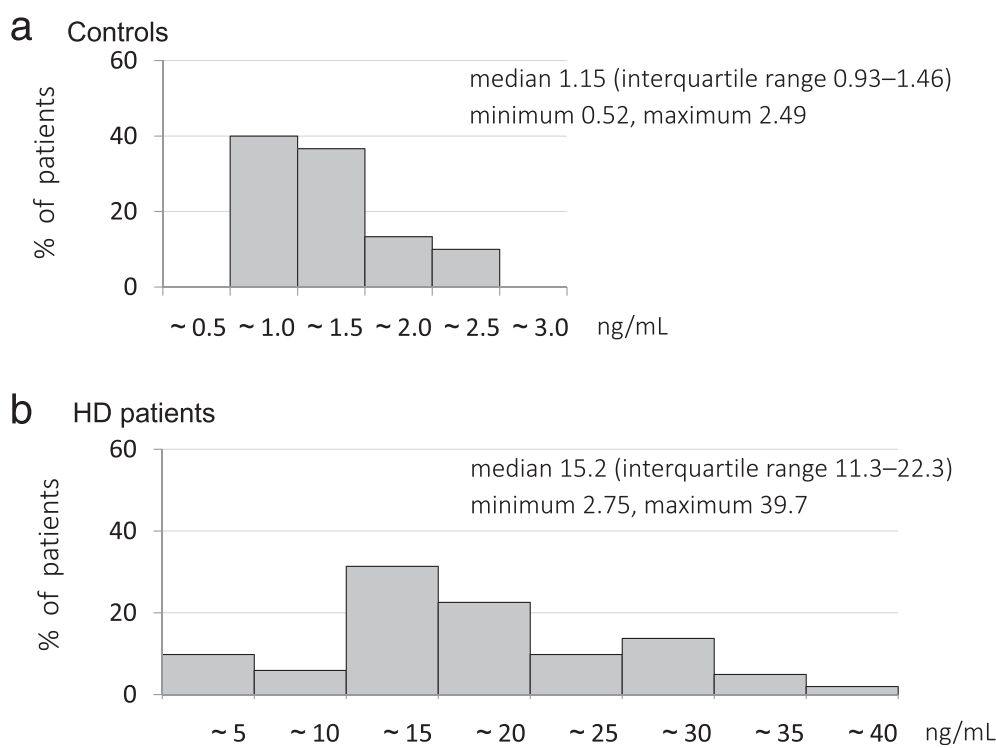

Fig. 4 Distribution of serum sclerostin levels in 30 controls (a) and 102 hemodialysis patients (b). a Median level $1.15 \mathrm{ng} / \mathrm{ml}$ (IQR 0.93-1.46 ng/ ml). b Median level $15.2 \mathrm{ng} / \mathrm{ml}(\mathrm{IQR} 11.3-22.3 \mathrm{ng} / \mathrm{ml})[44]$

PTH and FGF23 levels are present in dialysis patients with spontaneously low PTH levels who are not being treated with vitamin $\mathrm{D}$.

\section{Association between sclerostin and vascular calcification}

Vascular calcification results from a phenotypic conversion of vascular smooth muscle cells into an osteoblast-like phenotype [13] that involves induction of an osteoblast transcriptional activation of osteocyte-specific proteins, such as FGF23 and sclerostin, via a Wnt-dependent mechanism [45]. The characteristics of negative regulators of Wnt signaling can therefore be expected to prevent osteoblast maturation and the progression of cardiovascular calcification.

Sclerostin has been implicated in the pathogenesis of vascular calcification in postmenopausal women [46]. Several inhibitors of Wnt signaling, including FRPs, Dkk1, and sclerostin, are over-expressed in arterial walls, aortic valves, and atherosclerotic lesions and during vascular smooth muscle cell calcification [34, 47]. A post hoc analysis of the data of 100 prevalent hemodialysis patients monitored over a 2-year period demonstrated an association between higher serum sclerostin levels and improved survival [23]. A prospective cohort study of 673 incident dialysis patients also found that high serum sclerostin levels were associated with lower cardiovascular mortality over an 18-month period, but the association was less pronounced after 4 years [37]. On the other hand, the potential protective effect of sclerostin against cardiovascular disease is in clear conflict with the results of the preclinical studies reported above showing that antibodies to the Wnt antagonist Dkk1 ameliorated cardiovascular calcification against a background of low bone turnover [48]. However, elevated DKK1 level and decreased vascular klotho are not usually observed in patients with early CKD stage, and the result is not likely to be generalized.

Taken together, the above findings are consistent with a hypothesis that increased serum Wnt antagonist levels induce low bone turnover, thereby indirectly increasing the propensity for vascular calcification. In suspect of this hypothesis, the serum sclerostin levels of hemodialysis patients have been found to be positively associated with coronary and aortic valve calcifications, and higher expression of sclerostin has been observed close to calcified areas in explanted aortic valves from dialysis patients [47]. Moreover, the results of a recent study of prevalent hemodialysis patients indicated that serum sclerostin is an independent predictor of mortality [49].

\section{Conclusions}

An increase in the serum level of the Wnt antagonist sclerostin and repression of $\mathrm{Wnt} / \beta$-catenin signaling are among the growing list of disturbances linked to CKDMBD progression. These disturbances are consistent with a general reduction in bone anabolism that appears to be independent of osteoclast activity, suggesting that osteoblast activity is insufficient even in the context of the increased osteoclast activity observed in some cases of renal osteodystrophy, which in turn, suggests that additional mechanisms contribute to the diversity of the skeletal defects in CKD. 
The conflicting data regarding potential relationships between increased serum sclerostin levels and both cardiovascular disease and mortality underscore the need for further study. Extended investigation of pathologic mechanisms and pathways in clinical biopsy specimens and in clinical samples, across various tissues and CKD stages, will be helpful in generating additional hypotheses. However, additional longitudinal assessments in large patient populations will undoubtedly be of benefit in achieving a complete understanding of sclerostin's impact on clinically relevant endpoints. The current information regarding sclerostin and its role in CKD-MBD provides yet another example of the critical need to take a system biology approach to understanding the full import of changes associated with the pathogenesis of CKD-MBD.

\section{Competing interests}

The authors have no conflicts of interest to declare.

\section{Authors' contributions}

YA planned the review, searched the literature, and prepared the article. KT searched the literature and assisted in writing the article. KN planned the context of this article and assisted in writing the article. All authors read and approved the final manuscript.

Received: 29 September 2015 Accepted: 10 December 2015 Published online: 11 April 2016

\section{References}

1. Veverka V, Henry AJ, Slocombe PM, Ventom A, Mulloy B, Muskett FW, et al. Characterization of the structural features and interactions of sclerostin: molecular insight into a key regulator of Wnt-mediated bone formation. J Biol Chem. 2009;284:10890-900.

2. Hamersma H, Gardber J, Beighton P. The natural history of sclerosteosis. Clin Genet. 2003:63:192-7.

3. Balemans W, Ebeling M, Patel N, Van Hul E, Olson P, Dioszegi M, et al. Increased bone density in sclerosteosis is due to the deficiency of a novel secreted protein (SOST). Hum Mol Genet. 2001;10:537-43.

4. Brunkow ME, Gardner JC, Van Ness J, Paeper BW, Kovacevich BR, Proll S, et al. Bone dysplasia sclerosteosis results from the loss of the SOST gene product, a novel cysteine knot-containing protein. Am J Hum Genet. 2001;68:577-89

5. Li X, Ominsky MS, Niu QT, Sun N, Daugherty B, D'Agostin D, et al. Targeted deletion of the sclerostin gene in mice results in increased bone formation and bone strength. J Bone Miner Res. 2008;23:860-9.

6. Loots GG, Kneissel M, Keller H, Baptist M, Chang J, Collette NM, et al. Genomic deletion of a long-range bone enhancer misregulates sclerostin in Van Buchem disease. Genome Res. 2005:15:928-35.

7. Winkler DG, Sutherland MK, Geoghegan JC, Yu C, Hayes T, Skobier JE, et al. Osteocyte control of bone formation via sclerostin, a novel BMP antagonist. EMBO J. 2003:22:6267-76.

8. Van Bezooijen RL, Roelen BA, Visser A, van der Wee-Pals $L$, de Wilt $E_{1}$ Karperien M, et al. Sclerostin is an osteocyte-expressed negative regulator of bone formation, but not a classical BMP antagonist. J Exp Med. 2004; 199:805-14.

9. Poole KE, van Bezooijen RL, Loveridge N, Hamersma H, Papapoulos SE, Lowik CW, et al. Sclerostin is a delayed secreted product of osteocytes that inhibits bone formation. FASEB J. 2005;19:1842-4

10. Moe S, Drueke T, Cunningham J, Goodman W, Martin K, Olgaard K, et al. Kidney Disease: Improving Global Outcomes (KDIGO): definition, evaluation, and classification of renal osteodystrophy: a position statement from kidney disease: improving global outcomes (KDIGO). Kidney Int. 2006;69:1945-53.

11. Kidney Disease: Improving Global Outcomes (KDIGO) CKD-MBD Work Group. KDIGO clinical practice guideline for the diagnosis, evaluation, prevention, and treatment of Chronic Kidney Disease-Mineral and Bone Disorder (CKD-MBD). Kidney Int Suppl. 2009;113:S1-130.

12. Cannata-Andia JB, Roan-Garcia P, Hruska K. The connections between vascular calcification and bone health. Nephrol Dial Transplant. 2011;26:3429-36.

13. Nitta K. Vascular calcification in patients with chronic kidney disease. Ther Apher Dial. 2011;15:513-21

14. Krishnan V, Bryant HU, Macdougald OA. Regulation of bone mass by Wnt signaling. J Clin Invest. 2006;116:1202-9.

15. Baron R, Kneissel M. WNT signaling in bone homeostasis and disease: from human mutations to treatments. Nat Med. 2013:19:179-92.

16. Johnson ML, Kamel MA. The Wnt signaling pathway and bone metabolism. Curr Opin Rheumatol. 2007;19:376-82.

17. Dejana E. The role of Wnt signaling in physiological and pathological angiogenesis. Circ Res. 2010;107:943-52.

18. Vervloet MG, Massy ZA, Brandenburg VM, Mazzaferro S, Cozzolino M, UrenaTorres $P$, et al. Bone: a new endocrine organ at the heart of chronic kidney disease and mineral and bone disorders. Lancet Diabetes Endocrinol. 2014;2:427-36

19. Williams $\mathrm{BO}$. Insights into the mechanisms of sclerostin in regulating bone mass accrual. J Bone Miner Res. 2014:29:24-8.

20. Baron R, Hesse E. Update on bone anabolics in osteoporosis treatment: rationale, current status, and perspectives. J Clin Endocrinol Metab. 2012:97:311-25

21. Dallas SL, Prideaux M, Bonewald LF. The osteocyte: an endocrine cell... and more. Endocr Rev. 2013;34:658-90.

22. Canalis E. Wnt signaling in osteoporosis: mechanisms and novel therapeutic approaches. Nat Rev Endocrinol. 2013;9:575-83.

23. Viaene L, Behets GJ, Vlaes K, Meijers B, Blocki F, Brandenburg V, et al. Sclerostin: another bone-related protein related to all-cause mortality in haemodialysis? Nephrol Dial Transplant. 2013;28:3024-30.

24. Moorthi RN, Moe S. Recent advances in the noninvasive diagnosis of renal osteodystrophy. Kidney Int. 2013;84:886-94.

25. Jilka RL. Molecular and cellular mechanisms of the anabolic effect of intermittent PTH. Bone. 2007;40:1434-46.

26. Kramer I, Keller H, Leupin O, Kneissel M. Does osteolytic SOST suppression mediate PTH bone anabolism. Trends Endocrinol Metab. 2010;21:237-44.

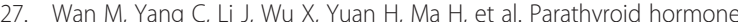
signaling through low-density lipoprotein-related protein 6. Genes Dev. 2008;22:2968-79.

28. Moe SM, Chen NX, Newman CL, Organ JM, Kneissel M, Kramer I, et al. Antisclerostin antibody treatment in a rat model of progressive renal osteodystrophy. J Bone Miner Res. 2015;30:539-49.

29. Cejka D, Herberth J, Branscum AJ, Fardo DW, Monier-Fauqere MC, Diarra D, et al. Sclerostin and Dickkopf-1 in renal osteodystrophy. Clin J Am Soc Nephrol. 2011;6:877-82.

30. Malluche HH, Davenport DL, Cantor T, Monier-Faugere MC. Bone mineral density and serum biochemical predictors of bone loss in patients with CKD on dialysis. Clin J Am Soc Nephrol. 2014:9:1254-62.

31. McNulty M, Singh RJ, Li X, Bergstralh EJ, Kumar R. Determination of serum and plasma sclerostin concentrations by enzyme-linked immunoassays. J Cin Endocrinol Metab. 2011;96(7):E1159-62.

32. Costa AG, Cremers S, Dworakowski E, Lazarett-Castro M, Bilezikian JP. Comparison of two commercially available ELISAs for circulating sclerostin. Osteoporos Int. 2014;25:1547-54.

33. Honasoge M, Rao AD, Rao SD. Sclerostin: recent advances and clinical implications. Curr Opin Endocrinol Diabetes Obes. 2014;21:437-46.

34. Thambiah S, Roplekar R, Manghat P, Fogelman I, Fraser WD, Goldsmith D, et al. Circulating sclerostin and Dickkopf-1 (DKK1) in predialysis chronic kidney disease (CKD): relationship with bone density and arterial stiffness. Calcif Tissue Int. 2012;90:473-80.

35. Cejka D, Marculescu R, Kozakowski N, Pischke M, Reiter T, Gessl A, et al. Renal elimination of sclerostin increases with declining kidney function. I Clin Endocrinol Metab. 2014:99:248-55.

36. Roforth MM, Fujita K, McGregor UI, Kirmani S, McCready LK, Peterson JM, et al. Effects of age on bone mRNA levels of sclerostin and other genes relevant to bone metabolism in humans. Bone. 2014;59:1-6.

37. Cejka D, Jager-Lansky A, Kieweg H, Weber M, Bieglmayer C, Haider DG, et al. Sclerostin serum levels correlate positively with bone mineral density and microarchitecture in haemodialysis patients. Nephrol Dial Transplant. 2012;27:226-30 
38. Pelletier S, Dubourg L, Carlier MC, Hadj-Aissa A, Fouque D. The relation between renal function and serum sclerostin in adults with CKD. Clin J Am Soc Nephrol. 2013;8:819-23.

39. Ishimura E, Okuno S, Ichii M, Norimine K, Yamakawa T, Shoji T, et al. Relationship between serum sclerostin, bone metabolism markers, and bone mineral density in maintenance hemodialysis patients. J Clin Endocrinol Metab. 2014;99:4315-20.

40. Drechsler C, Evenepoel P, Vervloet MG, Wanner C, Ketteler M, Marx N, et al. High levels of circulating sclerostin are associated with better cardiovascular survival in incident dialysis patients: results from the NECOSAD study. Nephrol Dial Transplant. 2015:30:288-93.

41. Sabbagh Y, Graciolli FG, O'Brien S, Tang W, dos Reis LM, Ryan S, et al. Repression of osteocyte Wnt/ $\beta$-catenin signaling is an early event in the progression of renal osteodystrophy. J Bone Miner Res. 2012;27:1757-72.

42. Bonani M, Rodriguez D, Fehr T, Mohebbi N, Brockmann J, Blum M, et al. Sclerostin blood levels before and after kidney transplantation. Kidney Blood Press Res. 2014;39:230-9.

43. Delanaye P, Krzesinski JM, Warling X, Moonen M, Smelten N, Medart L, et al. Clinical and biological determinants of sclerostin plasma concentration in hemodialysis patients. Nephron Clin Pract. 2014;128:127-34.

44. Asamiya Y, Yajima A, Shimizu S, Otsubo S, Tsuchiya K, Nitta K. Association between the levels of sclerostin, phosphate, and fibroblast growth factor-23 and treatment with vitamin $\mathrm{D}$ in hemodialysis patients with low intact PTH level. Osteoporos Int. 2015:26:1017-28.

45. Shao JS, Cheng SL, Pingsterhaus JM, Charlton-Kachigian N, Loewy AP, Towler DA. Msx2 promotes cardiovascular calcification by activating paracrine Wnt signals. J Clin Invest. 2005;115:1210-20.

46. Hampson G, Edwards S, Conroy S, Blake GM, Fogelman I, Frost ML. The relationship inhibitors of the Wnt signaling pathway (Dickkopf-1(DKK1)), bone mineral density, vascular calcification and arterial stiffness in postmenopausal women. Bone. 2013;56:42-7.

47. Brandenburg VM, Kramann R, Koos R, Kruger T, Schurgers L, Muhlenbruch G, et al. Relationship between sclerostin and cardiovascular calcification in hemodialysis patients: a cross-sectional study. BMC Nephrol. 2013;14:219.

48. Fang Y, Ginsberg C, Seifert M, Aqapova O, Sugatani T, Register TC, et al. CKD-induced wingless/integration1 inhibitors and phosphorus cause the CKD-MBD. J Am Soc Nephrol. 2014;25:1760-73

49. Goncalves FL, Elias RM, dos Reis LM, Graciolli FG, Zampieri FG, Oliveira RB, et al. Serum sclerostin is an independent predictor of mortality in hemodialysis patients. BMC Nephrol. 2014;15:190.

\section{Submit your next manuscript to BioMed Central and we will help you at every step:}

- We accept pre-submission inquiries

- Our selector tool helps you to find the most relevant journal

- We provide round the clock customer support

- Convenient online submission

- Thorough peer review

- Inclusion in PubMed and all major indexing services

- Maximum visibility for your research

Submit your manuscript at wuw biomedcentral.com/submit

) Biomed Central 